\title{
Da Efetividade e da Eficácia da Polícia Judiciária No Estado Democrático de Direito BRASILEIRO $^{1}$
}

\author{
José Pedro Zaccariotto ${ }^{2}$ \\ "Dize-me que polícia tens e eu dir-te-ei que democracia alcançaste."
}

\section{INTRODUÇÃo}

Em que pese a inegável expansão e o acentuado aprofundamento dos estudos que lhe foram dedicados ao longo dos últimos anos, a polícia judiciária, neste Brasil de início de milênio, teima em seguir se conformando como uma ilustre desconhecida, assim na exata medida em que, a despeito de ter assento constitucional, figurar em leis e, embora infrequente, ser discutida nos meios acadêmicos, ainda resta usualmente confundida em relação às suas funções e assim incompreendida quanto à sua importância, em quadro absolutamente comprometedor ao papel que se lhe aduz próprio e fundamental à promoção e preservação da liberdade individual.

Propõe-se, destarte, neste condensado trabalho, resgatar, a partir de insofismáveis premissas lógicas, de conteúdo fático e jurídico, o verdadeiro significado, as efetivas dimensões e a inexorável relevância dessa função, com vistas a desvelar os caminhos asseguradores de sua necessária eficácia no âmbito do Estado Democrático de Direito pátrio.

1 O presente artigo foi baseado na obra do autor titulada "A Polícia Judiciária no Estado Democrático", publicada pela editora Brazilian Books, em 2005, ISBN 85-99080-01-6, recebendo devida atualização e complementação cabível.

2 O autor, mestre em Direito Constitucional, Delegado de Polícia aposentado (PCSP), exerce presentemente a advocacia e o magistério policial (na Academia de Polícia “Dr. Coriolano Nogueira Cobra", no Estado de São Paulo) e universitário (Faculdade de Direito de Sorocaba e o Curso de Direito da UNIP - campus Sorocaba).

3 BERISTAIN Antonio. Ética policial segun las Naciones Unidas, p. 24. 


\section{Da Polícia Judiciária e sua Efetividade}

\subsection{DA GÊNESE Às TENTATIVAS DE PASTEURIZAÇÃo INSTITU- CIONAL}

Com o advento do Estado de Direito, foi a polícia despojada da amplitude que, desde os fins do século XIV até o crepúsculo do século XVIII, lhe fora conferida pelo denominado jus politiae, passando então a se apresentar singelamente como "uma função administrativa típica de prevenção de perigos e de manutenção da ordem pública", peculiar, ainda segundo Canotilho, àquele então propriamente denominado "Estado guarda-nocturno". ${ }^{4}$

Nesse contexto, e na França, essa "nova polícia", primeiramente sistematizada pela Lei de 3 do Brumário do ano IV (25 de outubro de 1795), logo se viu bipartida: de um lado, a polícia administrativa, incumbida "principalmente a prevenir os delitos" (art. 19), e, de outro, a polícia judiciária, investigativa, responsável pela colheita das provas necessárias para a decretação, pelos tribunais, da punição dos autores dos crimes não evitados pela primeira (art. 205).

Não muito depois, promulgado em 17 de novembro de 1808, e vigorando desde 1o de janeiro de 1811, o Code d'Instruction Criminelle manteve a polícia judiciária com suas funções estritamente investigatórias, assim conformando o modelo que logo se tornou paradigmático, influenciando a legislação processual penal de quase toda Europa e praticamente do resto do mundo ${ }^{67}$.

4 CANOTILHO, J. J. Gomes. Direito Constitucional e Teoria da Constituição, p. 88.

5 Textual: "A polícia judiciária investiga os delitos que a polícia administrativa não pode evitar que fossem cometidos, colige as provas e entrega os autores aos tribunais incumbidos pela lei de puni-los".

6 TORNAGUI, Hélio. Instituições de processo penal, p. 99.

7 MENDES JÚNIOR, João. O Processo Criminal Brasileiro, p. 247. 
Contudo, essa diferenciada polícia, nominal e finalisticamente judiciária, não logrou encontrar, no atribulado ambiente da época, e muito menos nas primeiras décadas seguintes, condições mínimas, principalmente de exercício eficiente e imparcial, para cedo vingar como função pública especializada, que no serviço à jurisdição possuía sua exclusiva e verdadeira razão de ser. ${ }^{8}$

Ao contrário, o que se pôde ver, através das práticas coetâneas, foi a plena desconsideração estatal da dimensão operativa dessa novel polícia, com o desprezo de sua natureza investigativa, manifestado com o engajamento dos órgãos nominalmente encarregados de sua execução na mantença, a qualquer custo, da ordem pública9 de plantão.

8 A justificar a célebre sentença de Velez Mariconde, na qual reputa à polícia judiciária a relevantíssima tarefa de administração da fase primária da Justiça Penal (Apud TOURINHO FILHO, Fernando da Costa. Processo Penal. 6. ed. São Paulo, Saraiva, vol 1., 1982, , p. 162).

9 José Afonso da Silva define abstratamente a ordem pública como "uma situação de pacífica convivência social, isenta de ameaça de violência ou de sublevação que tenha produzido ou que supostamente possa produzir, a curto prazo, a prática de crimes" (Curso de Direito Constitucional Positivo, p. 754). Contudo, noutra mão de direção, Sérgio Marcos de Moraes Pitombo, referindo-se ao Estado Democrático de Direito, e pondo-se a luz dos direitos individuais, preferia "cogitar-se da paz pública, emergente do binômio: tranquilidade social, não artificial, e ordem social, entendida como harmonia na comunidade" (Emprego de Algemas - Notas em prol de sua regulamentação. Inquérito Policial: Novas Tendências, p. 81). Refletindo, percebe-se que há uma boa diferença a marcar essas duas vertentes, surgindo a ordem pública como sempre realçava esse grande e saudoso processualista - como conceito impositivo, que não possui raízes na tranquilidade e na harmonia sociais, mas sim na pretensão de produzi-las mediante expedientes de força, artificiais, restritivos, aptos a inviabilizar ações e a coibir posturas potencialmente capazes de ensejarem práticas criminosa. Sob esse enfoque, a segurança pública seria promovida mediante a desgastada fórmula - a cada dia mais evidenciada como írrita - das "tropas na rua". Por essa via, com a utilização de técnicas de saturação do espaço urbano, aliadas ao emprego massivo de medidas restritivas e até invasivas, e.g., implantação de toque de recolher (destinado a manter eventuais desordeiros afastados das ruas durante determinados períodos do dia ou da noite) e a realização aleatória de buscas pessoais, acredita-se ser possível colocar um fim à criminalidade. Contudo, como é de se ponderar, não apenas essa estratégia possui altíssimo custo econômico e impõe notórios sacrifícios aos direitos e liberdades individuais das "pessoas de bem" da comunidade afetada, como também não produz tímidos frutos, limitados em termos de tempo e espaço, pois, à uma, se interrompida, tudo retornaria ao status quo ante, ensejando a volta dos criminosos 
Dessarte, como mero apêndice do Poder Executivo, não mereceu a polícia judiciária, e por muito tempo, atenção senão orgânica, restando, pois, no âmbito jurídico, relegada, no mais das vezes, aos estudos circunscritos às estritas raias de um ainda incipiente Direito Administrativo, que jamais foi capaz de dedicar ao tema enfoque e ordenação adequadas.

Deveras, não se pode deixar de reconhecer, com Sérgio Marcos de Moraes Pitombo, que "a polícia, enquanto judiciária, e o inquérito que ela faz, exsurgem administrativos, por sua atuação e forma, mas judiciários, nos seus fins" ${ }^{\prime 10}$. Em outras palavras, ao menos do ponto de vista teleológico, a adequada compreensão dessa função pública não pode ser alcançada senão no âmbito de perquirição exclusivo do direito processual penal.

De feito, como há muito cifrado por Mário Masagão, ao Direito Administrativo somente pode interessar o estudo da polícia administrativa, eis que a polícia judiciária, conforme concebida originalmente, e segundo a autonomia que lhe foi idealizada e concedida pelo Código do Brumário, somente deveria atuar, e decerto no plano da colheita dos elementos de prova, após o cometimento do crime, já então sob as normas do "direito judiciário penal". ${ }^{11}$

aos locais anteriormente policiados e então desguarnecidos, e, à duas, mesmo ao curso de sua execução, os delinquentes momentaneamente afugentados certamente iriam atuar em outras bandas, já que se torna impossível manter esse grandioso esquema em todas as ruas de todas as cidades. Não fosse só isso, mesmo no auge das teladas operações de ocupação militar dos espaços urbanos, ainda que havendo tanques de guerra e outros blindados nas ruas, inegavelmente não serviria tal aparato para conter, por exemplo, a violência doméstica, o cybercrime, ilícitos perpetrados no âmbito do sistema financeiro, a corrupção no mundo político etc. Como se percebe, a crença no estabelecimento de uma artificial ordem pública, em detrimento aos esforços de construção de uma verdadeira paz social, com toda certeza levará a sociedade a não alcançar uma ou outra.

10 Arquivamento do Inquérito Policial - Sua Força e Efeito. Op. cit., p. 22. Grifo não original.

11 MASAGÃO, Mário. Curso de Direito Administrativo, p. 191-192. 
Curial a aceitação, pois, de conclusão extremamente símplice, condizente ao fato do Direito Administrativo se ostentar intrinsecamente falho ao realizar a tarefa de moldar a polícia judiciária, ao menos enquanto entendida em seu sentido genético, como função estatal jungida singularmente aos fins da Justiça Criminal, e que apenas eventual e suplementarmente possa vir se dedicar à prestação direta de serviços ou à imposição de limitações à população, assim prestando obséquio aos fins inerentes à Administração Pública.

Ora, de fato e de direito, desde a sua gênese, há mais de duas centúrias em solo gaulês, a polícia judiciária caracteriza-se exatamente como a função estatal - e por vezes até nomina o próprio órgão do Estado encarregado do seu exercício - destinada à investigação, promovendo o aclaramento da autoria e das circunstâncias das infrações penais. Trata-se de conceito histórico e mundial, tecnicamente patenteado ${ }^{12}$, como Faustin Helie, transcrito por João Mendes Junior, há muito já ilustrava:

A polícia judiciária é o olho da justiça; é preciso que o seu olhar se estenda por toda a parte, que os seus meios de actividade, como uma vasta rede, cubram o território, afim de que, como a sentinella, possa dar o alarma e advertir o juiz; é preciso que os seus agentes, sempre promptos aos primeiros ruidos, recolham os primeiros indícios dos factos puníveis, possam transportar-se, visitar os lugares, descobrir os ves-

12 Vide, por exemplo, o comezinho conceito veiculado pelo verbete polícia judiciária no conhecidíssimo Vocabulário Jurídico de De Plácido e Silva: “Denominação dada ao órgão policial, a que se comete a missão de averiguar a respeito dos fatos delituosos ocorridos ou das contravenções verificadas, a fim de que sejam os respectivos delinqüentes ou contraventores punidos por seus delitos ou por suas infrações. A polícia judiciária é repressiva, porque, não se tendo podido evitar o mal, por não ter sido previsto, ou por qualquer outra circunstância, procura, pela investigação dos fatos criminosos ou contravencionais, recolher as provas que os demonstram, descobrir os autores deles, entregando-os às autoridades judiciárias, para que cumpram a lei" (1ª edição eletrônica. Rio de Janeiro: Forense, 1999). Idem Maria Helena Diniz, com evidente fulcro na legislação processual penal em vigência: "Polícia exercida pelas autoridades policiais, no território de suas respectivas circunscrições, com o intuito de apuração das infrações penais e de sua autoria" (Dicionário Jurídico, vol. 3, p. 624). 
tigios, designar as testemunhas e transmittir á autoridade competente todos os esclarecimentos que possam servir para a instrucção ou formação da culpa; ella edifica um processo preparatorio do processo judiciário; e, por isso, muitas vezes, ella possa tomar as medidas provisórias que exigirem as circumstancias. Ao mesmo tempo ela, deve apresentar em seus actos algumas das garantias judiciárias: que a legitimidade, a competência, as habilitações e as attribuições dos seus agentes sejam definidas, que os casos de sua intervenção sejam previstos, que seus actos sejam autorisados e praticados com as formalidades prescriptas pela lei; que, emfim, os effeitos destes actos sejam medidos segundo a natureza dos factos e a autoridade de que são investidos os agentes ${ }^{13}$ (sic)

Malgrado seja verdade que impende à polícia judiciária mais do que apenas investigar, cabendo-lhe, outrossim, e exemplificativamente, também a captura de criminosos condenados pela Justiça e a prestação de informações importantes à faina judicial (art. $13 \mathrm{CPP}$ ), avulta igualmente inequívoca a natureza complementar e secundária dessas atividades, desdobramentos óbvios do labor investigativo, que se resume na própria razão de ser policial judiciária. ${ }^{14} 15$

13 MENDES JÚNIOR, João. Op. cit., p. 246.

14 José Lisboa Gama Malcher, afirmando que à polícia judiciária incumbia lida investigatória, alinhava-lhe quatro funções básica, a saber: probatória, definida pelos arts. 6o, III a VIII, 7o, 8o, 11,13 e 14 do Código de Processo Penal; cautelar, prevista nos arts. 6o, I a III, e 11 desse Diploma; coercitiva, como a prisão em flagrante delito, a decretação do sigilo ou as medidas assecuratórias da indenização civil, e auxiliar, correspondendo àquelas elencadas no art. 13 do mesmo Código (Manual de Processo Penal Brasileiro, p. 112-114).

$15 \mathrm{O}$ equívoco da separação constitucionalmente promovida entre a atividade de investigação criminal e o exercício da função policial judiciária fica, assim, bem demonstrado, malgrado venha restar ainda definitivamente patenteado em face dos adminículos históricos, jurídicos, legais e doutrinários adiante colecionados neste trabalho. De qualquer forma, essa clara imprecisão já se encontro superada, qual se extrai do teor da Súmula Vinculante $n^{\circ} 14$ do Supremo Tribunal Federal, onde foi estabelecida uma irrefutável relação de inerência entre a atividade investigatória e competência de polícia judiciária. Textual: “"É direito do defensor, no interesse do representado, ter acesso amplo aos elementos de prova que, já documentados em procedimento investigatório realizado por órgão com competência de polícia judiciária, digam respeito ao exercício do direito de defesa." Grifado. 
Aliás, entre nós essa concepção também é centenária, decorrente da produção legislativa do Império, pertinente tanto à disciplina processual penal (Regulamento de 1842), quanto à matéria política (Lei de Interpretação - n⿳0 105, de 12 de maio de 1840 - do Ato Adicional de 1834, a Lei no 16, de 12 de agosto). Já Pimenta Bueno, celebrado jurista do Império, ensinava que a polícia judiciária é aquela que

tem a seu cargo rastrear e descobrir os crimes, que não puderam ser prevenidos, colher e transmittir ás autoridades competentes os indícios e provas, indagar quaes sejam os seus autores e cumplices, e concorrer efficazmente para que sejam levados aos tribunaes (sic). ${ }^{16}$

Esse mesmo e inconfundível sentido encontra-se patenteado no vigente Código de Processo Penal, em vigor desde 1941, que a respeito, e com clareza solar, elucida: "Art. 4º A polícia judiciária será exercida pelas autoridades policiais no território de suas respectivas circunscrições e terá por fim a apuração das infrações penais e da sua autoria."

Na mesma linha, no plano doutrinário, Canuto Mendes de Almeida coerentemente já advertia que "a polícia judiciária opera depois das infrações, para investigar a verdade e, a respeito, prestar informações à Justiça" ${ }^{17}$. Eis o convergente entendimento do não menos festejado José Frederico Marques: “a polícia judiciária não tem mais do que função investigatória". ${ }^{18} 19$

16 PIMENTA BUENO, José Antonio. Apontamentos Sobre o Processo Penal Brasileiro, p. 3. 17 ALMEIDA, J. Canuto Mendes de. Princípios Fundamentais do Processo Penal, p. 60. 18 MARQUES, José Frederico. Elementos de Direito Processual Penal - Vol. I, p. 146.

19 À idêntica conclusão chegam os autores contemporâneos, como é o caso, por exemplo, de Aury Lopes Jr., para quem “a polícia judiciária está encarregada da investigação preliminar, sendo desempenhada nos Estados pela Polícia Civil e, no âmbito federal, pela Polícia Federal." (Direito Processual Penal e sua conformidade constitucional, p. 249), e de Guilherme de Souza Nucci, que destaca a preocupação manifesta nas legislações mais recentes, qual ocorre com a Lei de Drogas (Lei n๑ 11.343/06), em atribuir expressa e exclusivamente à "autoridade de polícia judiciária" - "que obviamente não é a autoridade militar", enfatiza esse autor - as providência relacionadas à investigação criminal (Código 


\subsection{DO PONTUAL ESTRABISMO ADMINISTRATIVISTA}

É exatamente na vaza desse repertório, pois, que se impõe proceder a desmistificação de determinadas crenças provindas de lições ministradas na órbita do Direito Administrativo, e que acabam por lançar dúvidas sobre as efetivas dimensões da atividade policial judiciária, normalmente tendo como efeito a sua minimização técnica e jurídica, a começar pelas caracterizações, certamente azadas em decorrência da mencionada e primitiva dicotomização legal, que projetam, em contexto unicamente apto ao patrocínio de interminável barafunda, a polícia administrativa como responsável por exercício preventivo, e a polícia judiciária como incumbida do desempenho de função repressiva.

Tal classificação, malgrado imprecisa, manteve-se em voga por bastante tempo, não deixando, ainda hoje, de merecer a atenção e os escólios de nossos administrativistas, mesmo quando apenas para efeito de crítica. Eis a síntese promovida por José Cretella Júnior :

A polícia administrativa tem por escopo impedir as infrações das leis (sendo nesta parte preventiva) e sustentar a ordem pública em cada lugar, bem como em toda a parte do reino (JUSTINO ANTÔNIO DE FREITAS, Instituições de Direito Administrativo Português, $2 a$ ed., 1861, p. 192); assegurar a ordem e segurança públicas, a proteção dos direitos concernentes à liberdade, à vida e à propriedade, e bem assim, a prevenção dos delitos, por meio de ordens e determinações conducentes a tal fim (MATOS DE VASCONCELOS, Direito Administrativo, 1936, vol. I, p. 224). À polícia administrativa ou preventiva incumbe, em geral, a vigilância, proteção da sociedade, manutenção da ordem e tranqüilidade pública, bem assim, assegurar os direitos individuais e auxiliar a execução de atos e decisões da Justiça e da Administração (MATOS DE VASCONCELOS, Direito Administrativo, 1936, vol. I, p. 225).

de Processo Penal Comentado. 15ª ed. Rio de Janeiro: Forense, 2016, p. 54). 


\section{(...)}

A POLÍCIA JUDICIÁRIA é também denominada repressiva, nome que merece um reparo porque esse organismo não aplica apenas aos delitos, mas funciona como auxiliar do Poder Judiciário nesse mister. No mesmo sentido, escreve JUSTINO ANTONIO DE FREITAS : "polícia judiciária é a que procura as provas dos crimes e contravenções e se emprenha em descobrir os seus autores, cujo caráter a torna por isso essencialmente repressiva (Instituições de Direito Administrativo Português, 2 a ed., 1861, p. 192)." ${ }^{\prime 20}$

Com o passar tempo, mais e mais vozes foram se elevando para protestar contra a desatualização e a impropriedade dessa vetusta distinção, assim como para propor, em sentido inverso, a sua substituição por outras e divergentes segmentações, baseadas em critérios diversos.

Nessa senda, Di Pietro perfila alguns desses novos arranjos, dentre os quais vale destacar aquele propugnado por Álvaro Lazzarini, que aduz "a linha de diferenciação" entre as polícias administrativa e judiciária situada "na ocorrência ou não de ilícito penal". Assim, "quando atua na área do ilícito puramente administrativo (preventiva ou repressivamente), a polícia é administrativa. Quando o ilícito penal é praticado, é a polícia judiciária que age" ${ }^{21} \mathrm{E}$ mais ou menos nessa linha, a autora pontua :

Outra diferença: a polícia judiciária é privativa de corporações especializadas (polícia civil e militar), enquanto a polícia administrativa se reparte entre diversos órgãos da Administração, incluindo a própria polícia militar, os vários órgãos de fiscalização, aos quais a lei atribua esse mister, como os que atuam nas áreas de saúde, educação, trabalho, previdência e assistência social. ${ }^{22}$

20 CRETELLA JÚNIOR, José. Do Poder de Polícia, p. 45-46.

21 Apud DI PIETRO, Maria Silvia Zanella. Direito Administrativo, p. 112.

22 DI PIETRO, Maria Silvia Zanella. Ibidem, p. 113. 
Não se mantendo muito distante desse último raciocínio, mas também não abandonando a tradicional doutrina francesa, Cretella Júnior prega a existência, entre nós, de uma polícia que titula mista ou eclética, "que acumula ou exerce, sucessiva e simultaneamente, as duas funções, a preventiva e a repressiva, como é o caso da polícia brasileira, em que o mesmo órgão previne e reprime". ${ }^{23}$

Sem embargo do pronto e pleno reconhecimento da proverbial autoridade dos citados tratadistas, cremos que a óptica da qual parecem comungar, porque fiel apenas às tímidas perspectivas do Direito Administrativo, não permite a escorreita identificação da forma, e ainda menos do conteúdo, que se impõe imperativos a propriamente consubstanciar a função policial judiciária, máxime no Estado Democrático de Direito.

Com efeito, todas as teses encimadas, que miram a polícia em suas relações com a segurança pública, descrevem-na como atividade monolítica e indistinta, sempre evidenciada a partir de aspectos francamente secundários, de ordem temporal e orgânica. Renunciam, desse modo, perscrutá-la tal como hoje efetivamente se apresenta, jurídica e faticamente, a compor um conjunto de diversificadas e inconfundíveis funções, explicitado pelo art. 144 da vigente Carta Magna. Aí se encontra insculpido quadro discriminatório de atividades que, incontestavelmente, não podem ser tomadas como únicas ou coincidentes, tocantes a cada órgão e corporação elencados, qual adiante destacado:

$\S 1^{o}$ A polícia federal, instituída por lei como órgão permanente, organizado e mantido pela União e estruturado em carreira, destina-se a:

I - apurar infrações penais contra a ordem política e social ou em detrimento de bens, serviços e interesses da União ou de suas entidades autárquicas e empresas públicas, assim como outras infrações cuja prática tenha repercussão interestadual

23 CRETELLA JÚNIOR, José. Op. cit., p. 47. 
ou internacional e exija repressão uniforme, segundo se dispuser em lei;

II - prevenir e reprimir o tráfico ilícito de entorpecentes e drogas afins, o contrabando e o descaminho, sem prejuízo da ação fazendária e de outros órgãos públicos nas respectivas áreas de competência;

III - exercer as funções de polícia marítima, aeroportuária e de fronteiras;

IV - exercer, com exclusividade, as funções de polícia judiciária da União.

$\S 2^{o}$ A polícia rodoviária federal, órgão permanente, organizado e mantido pela União e estruturado em carreira, destina-se, na forma da lei, ao patrulhamento ostensivo das rodovias federais."

$\S 3^{0}$ A polícia ferroviária federal, órgão permanente, organizado e mantido pela União e estruturado em carreira, destina-se, na forma da lei, ao patrulhamento ostensivo das ferrovias federais."

$\S 4^{0}$ - às polícias civis, dirigidas por delegados de polícia de carreira, incumbem, ressalvada a competência da União, as funções de polícia judiciária e a apuração de infrações penais, exceto as militares.

$\S 5^{\underline{0}}$ - às polícias militares cabem a polícia ostensiva e a preservação da ordem pública; aos corpos de bombeiros militares, além das atribuições definidas em lei, incumbe a execução de atividades de defesa civil.

Parece claro, destarte, que não devem restar dúvidas sobre qual órgão ou corporação deve desenvolver essa ou aquela função policial, assim como não mais se pode admitir, em conformidade a pretensão de alguns, manifestadas no isolado âmbito do Direito Administrativo, que todas venham a se resumir na polícia judiciária. Aos adeptos de expedientes classificatórios parece melhor, à vista do transcrito texto da Lei Fundamental, e como já se faz corriqueiro, referir-se, como gênero, e perfazendo 
denominação temática, a uma polícia de segurança, conformada, no entanto, por particularizados órgãos e corporações, cada qual detentor de distintas funções.

Em todo o caso, face às consignadas disposições constitucionais, certamente não se ostenta razoável asseverar, por exemplo, que à polícia ferroviária federal ou às polícias militares dos Estados impende o exercício das atividades de polícia judiciária, ou seja, como patenteado, de investigação criminal, tanto quanto deve se ter por despropositado desejar que as polícias civis estaduais se ocupem do patrulhamento ostensivo.

Malgrado a obviedade destas ponderações, releva considerar que o desconhecimento generalizado acerca da verdadeira polícia judiciária repousa, também, no fato que, entre nós, em tempo algum foi ela efetiva e eficazmente implantada. Ou seja, nunca existiu, como atualmente continua inexistindo no Brasil - malgrado sua imprescindibilidade à depurada e eficiente realização de uma justiça criminal que possa ser qualificada como democrática uma polícia exclusivamente investigativa, estritamente dedicada, em consonância à sua verdadeira especialização, ao esquadrinhamento das infrações penais, e a se configurar apenas num segundo plano proveitosa também à segurança pública (direito e responsabilidade de todos, ex vi art. 144, "caput", CR).

Essa realidade - fruto induvidoso da pouca intimidade brasileira com a democracia e seus valores - tem levado alguns exegetas à confusão, e daí a apontar como inerentes ao exercício policial judiciário determinadas ações, amiúde praticadas por órgãos e corporações integrantes da referida polícia de segurança, exclusiva e constitucionalmente designados ao desempenho da polícia ostensiva e de preservação da ordem pública.

Di Pietro, nessa conjuntura, arrola a apreensão de uma arma de fogo indevidamente utilizada ou ainda da licença do 
motorista infrator como exemplos da comezinha atuação repressiva $^{24}$ desses órgãos e corporações, que por essa razão ganhariam status policial judiciário. ${ }^{25}$

Nessa linha, Hely Lopes Meirelles afirmou que, "em circunstâncias excepcionais, pode a Polícia Militar desempenhar função de polícia judiciária", circunscrevendo, porém, essa possibilidade, a determinadas ações de força, "tal como na perseguição e detenção de criminosos, apresentando-os à Polícia Civil para o devido inquérito a ser remetido, oportunamente à Justiça Criminal" ${ }^{26}$

Todavia, o desacerto desses entendimentos, de alcance extremamente facilitado, se encontra definitivamente consolidado pelo Supremo Tribunal Federal, que ao decidir a ADI 3614, julgou inconstitucional o Decreto no 1.557/03 do Estado do Paraná, que permitia a policiais militares a elaboração de termos circunstanciados de ocorrência, nos municípios que não dispunham de servidor de carreira para o desempenho das funções de Delegado de Polícia. Neste caso, a transferência de atividades de polícia judiciária a integrantes de corporações policiais que não foram constitucionalmente contempladas com essa atribuição, ainda que em circunstâncias excepcionais, foi considerada uma grave ofensa ao art. 144, caput, inc. IV e V e $\S \S 4^{{ }^{\circ}}$ e 5을 da Lei Fundamental. ${ }^{27}$

24 Ressalte-se o erro que carrega a ideia de que mera atuação repressiva possa automaticamente impingir feição e natureza policial judiciária aos feitos da polícia administrativa. É cediço, consoante lições tiradas à saciedade do Direito Público, que a polícia administrativa também age repressivamente, qual precisamente aclara Carlos Ari Sundfeld: "Entre as competências da Administração ligadas aos condicionamentos de direito, insere-se a de repressão da sua inobservância. A atividade repressiva é veiculada por instrumentos com variada finalidade e intensidade. Dentre eles, devem-se distinguir três, especialmente relevantes: a) a ordem para correção de irregularidades; b) a medida cautelar; e c) a sanção." (Direito Administrativo Ordenador, p. 77).

25 Op. cit., p. 112.

26 MEIRELLES, Hely Lopes. Polícia de Manutenção da Ordem Pública e suas Atribuições. Direito Administrativo da Ordem Pública, p. 87-93.

27 STF. ADI 3614/PR. Relator: Min. GILMAR MENDES - Relatora p/ Acórdão Min. CÁRMEN LÚCIA - 20/09/2007 - Tribunal Pleno - DJe-147. 
E esse posicionamento foi confirmado quando do julgamento do Recurso Extraordinário no 702.617 , em que restou reconhecida a inconstitucionalidade da Lei no 3.514/10 do Estado do Amazonas, que também concedia a integrantes da Polícia Militar a faculdade de elaborar termos circunstanciados de ocorrência. Decidiu o Pretório Excelso que, igualmente nesse caso, houve usurpação de competência:

O dispositivo legal que atribui à Polícia Militar competência para confeccionar termos circunstanciado de ocorrência, nos termos do art. 69 da Lei no 9.099/1995, invade a competência da Polícia Civil, prevista no art.115 da Constituição do Estado do Amazonas, e se dissocia da competência atribuída à Polícia Militar constante do art. 116 da Carta Estadual, ambos redigidos de acordo com o art. 144, $\S \S 4^{\underline{0}}$ e $5^{\circ}$, da Constituição Federal. ${ }^{28}$

\subsection{DESFAZENDO EQUívocos: PARA A CABAL COMPREENSÃo do CONTEÚdo FÁtico E JURídico da POLÍCIA JUDICIÁRIA.}

Assoma-se essencial, nesse diapasão, ainda considerar que as atividades acima elencadas, por reconhecidos administrativistas, como se fossem atos de polícia judiciária -encontro ocasional e/ou fortuito de provas, apreensões e até mesmo a prisão de alguém surpreendido em flagrante delito -, podem perfeitamente ser ultimadas por qualquer cidadão, até mesmo, v.g., pela vítima de um crime que, em sua reação, venha a desarmar e imobilizar o seu agressor, conduzindo-o, incontinenti, à presença da autoridade policial, para as providências de atribuição exclusiva dos órgãos constitucionalmente incumbidos do verdadeiro exercício policial judiciário .

Denotam, pois, as focalizadas colocações, que a grande maioria daqueles que se mantém distantes da lida policial judi-

28 STF. RE 702617 AgR/AM - Relator Min. LUIZ FUX - 26/02/2013 - Primeira Turma DJe-054. 
ciária pouco consegue guardar além de uma pálida noção acerca do seu concreto desenvolvimento, costumando imaginar, com inelutável diletantismo e demasiada simploriedade, que as atividades investigativas sempre tem por elemento propulsor um fato incontroverso, sobejamente caracterizado - fática e juridicamente - como crime, azando ilação fácil e inequívoca, lastreada por um abundante e induvidoso rol de provas.

Longe, entrementes, se acha essa suposição de se compatibilizar minimamente com a realidade, uma vez que parte considerável das notitia criminis que chegam aos órgãos policiais judiciários dizem respeito a fatos por vezes até induvidosamente ilícitos, porém carentes de comprovação quanto à sua efetiva natureza, se civil ou criminal, como ocorre, e com grande freqüência, em face de casos permeados por hipotéticos descumprimentos de obrigações assumidas, normal e insistentemente interpretados, pela parte que se sentir prejudicada, como estelionatos e apropriações indébitas, por exemplo, mercê da tênue linha que demarca a fronteira das aludidas espécies infracionais.

À polícia judiciária cabe, nesses e em tantos outros casos semelhantes - que refogem ao pouco criativo imaginário daqueles que se cingem à perquirição telescópica do seu rústico cotidiano -, laborar com vistas não à descoberta do autor dos fatos que se lhe são apresentados - invariavelmente de forma sintética e parcial por um irado reclamante -, mas, sim, e antes de mais nada, com o escopo de desvendar se esses fatos realmente se subsumem ou não a alguma hipótese delituosa. ${ }^{29}$

Toda essa intensa e especializada atividade investigativa, noutras vezes desencadeada à persecução da autoria de um

29 Para a perfeita compreensão da complexidade dessa tarefa, cuja adequada execução impõe percuciente ciência jurídica, vide a excelente monografia de Eliomar da Silva Pereira, "Convencionalismo e dogmatismo no conceito de crime como objeto de investigação criminal." (Doutrinas essenciais: Direito Penal e Processo Penal. BADARÓ, Gustavo Henrique (org.). São Paulo: Editora RT, vol. VI, 2015, p. 359-388). 
crime já confirmado como tal e/ou do aclaramento das circunstâncias em que foi cometido, revela-se como pesquisa de índole técnico-jurídica, totalmente balizada por preceitos processuaisconstitucionais ${ }^{30}$, e que, portanto, não pode ser confundida, mormente em termos de extensão, complexidade e importância, com breves e singelos atos de força, de caráter meramente dissuasório e emergencial, que fundem a breve práxis da polícia ostensiva e de preservação da ordem pública.

Salta à vista, desse modo, que o exercício eventual, contido, circunstancial e limitado de certos e diminutos expedientes coativos, geralmente facultados a qualquer um do povo, e que se baldariam a míngua das hábeis, tempestivas e sentenciosas providências validantes da exclusiva alçada da autoridade policial judiciária, devem necessariamente circunscrever-se tão-somente dentro das expectativas de preservação da ordem pública, constituídas com vistas ao asseguramento do primado da ordem jurídica, que restaria ao desabrigo, condenado ao perecimento, se aqueles que a infringissem pudessem continuar o seu curso sem ser obstado por quaisquer corporações, órgãos ou agentes do Estado, quando existentes e em condições de fazê-lo.

30 Vide, dentre tantas outras diligências de idêntica relevância e que demandam apurados conhecimentos técnicos e/ou jurídicos para as suas profícuas ultimações: interceptações de conversações telefônicas e ambientais; coleta de material genética e a pesquisa e identificação de DNA; localização, apreensão e decodificação de arquivos informatizados e de registros financeiros e contábeis; localização das posições dos investigados nos momentos circundantes ao crime, por meio de pesquisas relacionadas aos correspondentes aparelhos de telefonia celular etc. Como já tivemos a oportunidade de afirmar antes, "Assemelha-se o trabalho da autoridade policial ao do historiador, que é o profissional que ordena cronologicamente, examina metodicamente, interpreta e explica fatos havidos no passado. Antes, porém, pesquisa, investiga, vai ao sítio dos fatos, desenterra e garimpa provas, selecionando-as e cotejando-as, para, depois, a lume da melhor técnica e da Ciência, aferir procedência e autenticidade. Somente após finalizado todo esse trabalho é que poderá sopesar os resultados hauridos, para então, criteriosa, imparcial e inteligentemente, anunciar suas conclusões, as quais, é claro, deverão manter racional correspondência com as descobertas realizadas." (Portaria DGP 18/98 e Polícia Judiciária Democrática, p. 479). 
Diogo de Figueiredo Moreira Neto, buscando bem diferenciar as polícias administrativa e judiciária, explica justamente que:

(...) o uso da força pela Polícia Judiciária se volta à coação legal de pessoas singularmente consideradas (indiciados e acusados) absolutamente necessária à sua condução às barras dos tribunais, que faz a repressão a posteriori. O uso da força pela Polícia Administrativa, preventiva e repressivamente, se dirige contra a ação de pessoas, singularmente ou coletivamente consideradas, que, na prática de ações, criminais ou não, ocasionem perturbação da ordem pública, fazendo a repressão no momento em que ela ocorra, até restabelecê-la. ${ }^{31}$

Não vai longe, ademais, o magistério de Celso Antonio Bandeira de Mello :

O que efetivamente aparta polícia administrativa de polícia judiciária é que a primeira se dispõe unicamente a impedir ou paralisar atividades anti-sociais, enquanto a segunda se preordena à responsabilização dos violadores da ordem jurídica. ${ }^{32}$

Diante do todo exposto, parece inexorável o reconhecimento que consiste um enorme e descabido exagero procurar igualizar funções e atuações tão distintas como aquelas, de um lado encomendadas à polícia ostensiva e de preservação da segurança pública, e de outro, cabíveis à polícia judiciária. À primeira somente cabe agir esporadicamente após o crime, jamais com sentido investigatório, mas apenas, e de forma continengial, buscando o restabelecimento da ordem rompida, quando fática e temporalmente possível. Mesmo quando eventualmente chegar a recolher um determinado elemento de prova (o que também pode ocorrer pelas guardas municipais, seguranças de um estabelecimento público ou privado

31 MOREIRA NETO, Diego de Figueiredo. Direito Administrativo da Segurança Pública. Direito Administrativo da Ordem Pública, p. 65-86.

32 BANDEIRA DE MELLO, Celso Antonio. Curso de Direito Administrativo, p. 710. 
etc.), não deixa de representar um minus, em nada comparável ao plus em que se assoma a atividade investigatória consolidada pela segunda no inquérito.

Aduz-se imprescindível ter em mente que a investigação criminal induz os seus executores, no bojo das apurações que se lhes incumbe, a necessariamente se imiscuir na vida privada e por vezes até na intimidade dos suspeitos, ou seja, em terrenos extremamente delicados e quebradiços, onde, à míngua do domínio do Direito e de uma razoável sensibilidade jurídica, certamente provocarão muitos danos. Dessa forma, há de se perceber que o labor investigativo, naturalmente num Estado que tem por fundamento a dignidade da pessoa, impõe indefectivelmente aos seus operadores a atuar com precisão cirúrgica, sob pena de promoverem irrecuperáveis danos a direitos fundamentais, notadamente à liberdade individual.

A identificar, portanto, as polícias ostensiva e judiciária, e quando muito, apenas a pertença, como acima mencionado, a um mesmo gênero, qual seja o da polícia de segurança, que José Afonso da Silva assim delineia, não sem deixar de sequencialmente departi-las: "A atividade da polícia realiza-se de vários modos, pelo que a polícia se distingue em administrativa e de segurança, esta compreende a polícia ostensiva e a polícia judiciária." 33

Porém, sequer essa ideia se apresenta adequada, posto que exsurge mais que apenas conveniente, e sim impositivo afastar da polícia judiciária, a bem de seus súperos objetivos, a responsabilidade direta pela realização da segurança pública. De efeito, a ideia de alavancamento de investigações voltadas à promoção da segurança, ao invés de subordinada às exigências da liberdade, torna atividade ilegítima num verdadeiro Estado Democrático de Direito.

33 SILVA, José Afonso. Curso de direito constitucional positivo, p. 754-755. 
É Ferrajoli, o grande sistematizador do garantismo, quem assevera que as atividades policiais, num Estado comprometido com a efetiva defesa das instituições democráticas e, destarte, inteiramente voltado à proteção da dignidade humana, deveriam se limitar a apenas três, quais sejam, a investigativa, a preventiva e as executivas e auxiliares da jurisdição e da administração. E mais importante, ressalta esse douto publicista que essas distintas funções ditas policiais

deveriam estar destinadas a corpos de polícia separáveis entre eles e organizados de forma independente não apenas funcional, mas, também, hierárquica e administrativamente, em particular, a polícia judiciária, destinada, à investigação dos crimes e a execução dos provimentos jurisdicionais, deveria ser separada rigidamente dos outros corpos de polícia (...). ${ }^{34}$

\section{Da Polícia Judiciária e das Condições para a sua Eficaz Atuação no Processo Penal Democrático}

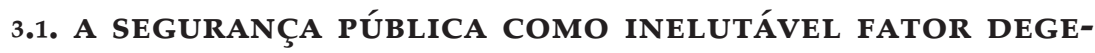 NERATIVO.}

As precedentes assertivas devem servir, no mínimo, para suscitar uma acendrada meditação acerca da razoabilidade em se conceber a polícia judiciária como função inerente à segurança pública, ao menos em se mirando os genuínos objetivos de um verdadeiro Estado Democrático de Direito.

Ninguém desconhece que a ameaça social representada pelo delito - não interessa se real ou não -, frequentemente oferece amplas margens para toda espécie de manipulação da opinião pública através do discurso político do crime, centrado na "ideia absolutamente imprestável de que o Direito Penal é instrumen-

34 FERRAJOLI, Luigi. , Direito e Razão: Teoria do Garantismo Penal, p. 617. Grifo não original. 
to suficiente para esbater a criminalidade e a violência, fenômenos de causação complexa e merecedores de tratamento conjugado, no qual a lei penal (e processual penal) desempenha modesta parte de tal função", consoante Dotti. ${ }^{35}$

A partir dessa concepção absolutamente equivocada, as medidas consequentemente propostas à solução do grave problema criminal teimam em sempre se pautar pela extrema simploriedade, apresentando-se recorrentemente jungidas ao incremento do rigor das leis penais, com tipificação de novas condutas e a elevação geral das penas, maiores restrições ao direito de defesa etc. ${ }^{36}$. Hassemer assinala que nesse encadeamento "a política criminal reduz-se à política de segurança", não indo está, a sua vez, além, de "desejos policiais de exacerbação e ampliação dos meios de combate ao crime". ${ }^{37}$

Nesse diapasão, o discurso político contra o crime propicia a constante presença na mídia, motiva promessas e enseja bravatas, em atividades sempre dotadas de grande potencial eleitoral. Eis o lúcido escólio de Theodomiro Dias Neto : “

Não há tema capaz de exercer tanto fascínio e polarização quanto a segurança pública. Paradoxalmente, não há tema mais deturpado e incompreendido. Tentativas de ser repensado a partir de óticas diversas, são rejeitadas pela lógica imediatista dos calendários eleitorais ou dos índices de audiência. ${ }^{38}$

Como a ninguém escapa, a segurança pública, justamente por conta do interesse que desperta na população, já há um bom tempo tem figurado como um dos principais temas das campanhas eleitorais, especialmente nas disputas das chefias dos Exe-

35 DOTTI, René Ariel. Reforma penal brasileira, p. 436.

36 Ibidem, p. 437.

37 HASSEMER, Winfried. Op. cit., p. 56.

38 DIAS NETO, Theodomiro. Segurança Pública: Um conceito a ser repensado, p. 12. 
cutivos estaduais. Nesse cenário, como facilmente se constata, o discurso invariavelmente gravita em torno do lugar comum inerente à otimização do funcionamento das organizações policiais, trazendo a reboque um sem-número de planos vazios, promessas atinentes à recomposição ou majoração dos respectivos quadros, à aquisição de recursos materiais relacionados ao exercício das atividades afins (em regra armamentos, viaturas e outros visíveis e simbólicos equipamentos) e, infalivelmente, à utilização de técnicas e estratégias, geralmente importadas de países do chamado primeiro mundo, cujas realidades em tudo discrepam daquela constatada em nosso país, mas que supostamente incrementariam significativa e automaticamente, senão miraculosamente, a contenção da criminalidade.

Alude-se frequentemente a uma polícia rígida, dura, inclemente com os infratores da lei, e, no auge das fanfarrices, chega-se até mesmo a garantir a expressiva e célere reversão dos aviltantes índices criminais, o que, e quando muito, vem a se esboçar por meio do manejo de estatísticas de todas as ordens e dotadas de todas as serventias, sempre produzidas pela fiel burocracia com o propósito de comprovar a existência de um ou outro aspecto positivo na gestão da segurança - e.g., se por um lado a taxa de homicídios aumentou, de outro o número de furtos de veículos recuou...

Nessa toada, premida pela lógica carreirista dos governantes, a polícia judiciária se vê irremediavelmente deturpada, transformada, adquirindo, sob o influxo de interesses claramente eleiçoeiros, feição e vocação quixotescas, porquanto compulsoriamente empenhada no combate - com as armas que dispuser - de uma amorfa e difusa criminalidade.

O desejo de propiciar segurança, que em seu nascedouro emerge tão lídimo quanto obrigatório aos nossos governantes, logo irá tornar-se ilegítimo se porventura conspurcar, em sua concretização, o espírito democrático que deve vivificar e balizar 
o exercício da função policial judiciária, mediante a utilização dos órgãos e dos agentes que se lhe encontram constitucionalmente afetos em qualquer âmbito de atuação estranho àquele estritamente investigativo e de perseguição isenta dos objetivos da justiça criminal. ${ }^{39}$

De efeito, a missão investigatória confiada à polícia judiciária, como instrumento de realização de justiça, impõe que a detenção do criminoso jamais seja considerada mais importante ou dissociada da prévia captura da verdade dos fatos apura$\operatorname{dos}^{40}$. E a busca da verdade exige daquele que a promove a maior isenção possível em face dos fatos perquiridos, um grau de imparcialidade que dificilmente poderá ser obtido, ao menos fora do mundo meramente hipotético, daquele que é visto e a todo o momento cobrado, inclusive pela opinião pública ignara, como o responsável, pura e simplesmente, pela "preservação da ordem pública e da incolumidade das pessoas e do patrimônio" ${ }^{41}$.

Ora, uma vez vergado sob o peso dessa grandiosa tarefa, por cujo sucesso será indistinta e insistentemente reclamado pela sociedade ávida por sentir-se segura, restará ao responsável pelas atividades policiais judiciárias condições reais e ideais de levar a cabo esse trabalho com a serenidade, a ponderação, o apurado senso crítico e a imparcialidade que se lhes afiguram imprescindíveis?

39 O desprezo a essa regra somente servirá a fomentar o surgimento e o fortalecimento de um subsistema penal de polícia e de ordem pública, aos moldes daquele que foi tão claro e negativamente delineado por Ferrajoli (op. cit., p. 614-615), totalmente fundado nas instâncias de defesa social e em desacordo com os princípios garantidores da liberdade pessoal, cujo objetivo resume-se na "prevenção dos crimes e, de maneira mais geral, das turbações da ordem pública, feito através da defesa social ante ou extra delictum, aplicado por via administrativa a sujeitos 'perigosos' ou 'suspeitos'"' (ou ainda o condenado, o ocioso, o reincidente ou qualquer outro rótulo de sentido e efeitos próximos).

40 CUNHA RODRIGUES, José Narciso. Para um novo conceito de polícia, p. 408.

41 A paupérrima fórmula ínsita no caput do art. 144 da Constituição de 1988 a definir as finalidades da segurança pública. 
Rusconi responde não a essa questão, atribuindo a essa mescla das atividades policiais preventivas e investigativas o rótulo de "promiscuidade funcional", porquanto convicto de que, como fruto dessa perniciosa amálgama, a "tendência autoritária proveniente da atividade preventiva invade aos poucos as tarefas de investigação processual". ${ }^{42}$

Essa promiscuidade expressada por Rusconi, que como visto encontra pleno eco em Ferrajolli, certamente será potencializada em face da nossa cruel realidade, onde "o atrevimento e a impassibilidade do arbítrio criminal cruzam incessantemente nossa mídia e nossa cabeça, desencadeando torrentes de intimidação e indignação", eliminando, ainda segundo Hassemer, "qualquer concepção de segurança pública asseguradora da liberdade". ${ }^{43}$

E o elevado risco decorrente dessa mixórdia policial, embora de todo atual, se vê de há muito conhecido, como se extrai do célebre e inelutável vaticínio de Benjamin Franklin: "Uma sociedade que se propõe a trocar sua liberdade por sua segurança, em última instância, não terá e não merecerá nenhuma das duas".

\subsection{POLÍCIA JUdiCIÁRIA: FUNÇÃO ESSENCIAL À JUSTIÇA CRI- MINAL.}

Como de há muito assente, à polícia judiciária impende, nas palavras de Velez Mariconde, a relevantíssima tarefa de administração da fase primária da Justiça Penal ${ }^{44}$. Nessa mesma linha, escorreitamente reconhece Paulo Dá Mesquita que a investigação criminal ressuma assunto pertinente à justiça, devendo ser tratado, portanto, e com o grau de especialização que a temática exige, no estrito âm-

42 RUSCONI, Maximiliano A. Reformulación de los sistemas de justicia penal em América Latina y policía: algunas eflexiones, p. 194. Grifos não originais.

43 HASSEMER, Winfried. Op. cit., p. 58

44 Apud TOURINHO FILHO, Fernando da Costa. Processo Penal, p. 162. 
bito do processo penal ${ }^{45}$. E outra não é a lição de Winfried Hassemer, que após sustentar que "o direito processual penal não é outra coisa senão direito constitucional aplicado" proclama, com os pés firmes na realidade, que "isto vale com mais ênfase no tocante às medidas de força do inquérito policial" ${ }^{46}$. Corrobora-o Roberto Pérez Martinez:

O papel que ocupa a polícia no âmbito do processo penal de modo algum pode ser considerado secundário ou acessório, já que constitui um elemento essencial e determinante em sua própria configuração e desenvolvimento, decisivo por refletir a própria atividade jurisdicional, dai que necessariamente deva ser tratada nos seus justos termos, na importância que tem no marco processual penal. Para dizê-lo nas palavras de Andrés Ibañez é 'o melhor indicador da qualidade ou falta de qualidade democrática da justiça que é administrada por um determinado sistema judicial'.47

A toda evidência, consiste, pois, a polícia judiciária, como sobejamente demonstrado, função essencial à justiça criminal, não lhe sendo permitido, nessa condição, prestar contribuição alguma à segurança pública e/ou individual senão trilhando os únicos caminhos que à vista dessa elevada missão se lhes afiguram consentâneos, ou seja, senão através da incessante busca da verdade sobre um fato teoricamente infracional, assim mourejando com vista a dois objetivos de idêntica e extremada importância, destituídos de qualquer expressão de preponderância entre si, a saber: (i) evitar que acusações infundadas, levianas e até caluniosas injustamente arrastem inocentes às barras dos tribunais; e, (ii) possibilitar a exata e justa aplicação do Direito, sempre na ambitude processual, àqueles que realmente transgrediram as leis penais. ${ }^{48}$

45 MESQUITA, Paulo Dá. Notas sobre inquérito penal, polícias e Estado de direito democrático (suscitadas por uma proposta de lei dita de organização da investigação criminal), p. 138.

46 HASSEMER, Winfried. Op. cit., p. 62.

47 MARTINEZ, Roberto Perez. La policía judicial en el Estado democrático de derecho, p. 165.

48 ZACCARIOTTO, José Pedro. Op. cit., 479. É o que professa Colomer : “(...) as metas 
Nessa perspectiva, divisada em face dos estritos lindes constitucionais e democráticos, resta à polícia judiciária, no que tange à construção da segurança pública, uma contribuição tão especial quanto específica, de natureza reflexa, absolutamente fulcrada na sua capacidade de servir eficientemente à justiça criminal. Ora, o que poderia, no universo de um Estado de Direito, ostentar-se mais legítimo ao enfrentamento do crime (não ao combate sem tréguas à criminalidade) e de suas consequências do que o direito penal, quando sábia e justamente aplicado?

Como tantas vezes já se disse alhures, exsurge a impunidade como expressão acabada de ausência de justiça, quase como um incentivo à criminalidade. É um fato inconteste, e, aliás, notório que a impunidade mostra-se uma decorrência tão natural quanto desastrosa, tão lógica quanto perversa, da inexistência ou da improficuidade da genuína e depurada atividade investigativa, que, como demonstrado, histórica, legal e doutrinariamente perfaz a alma da função policial judiciária.

Não é demais pontuar, mormente com acentuada carga de transparência, que uma investigação, por definição, compreende a atividade que colima a verdade sobre fatos não ou insuficientemente conhecidos. E essa persecução, no campo penal, como não poderia se dar diferente num Estado Democrático, somente poderá ser pautada pela isenção, pela lealdade e pela ética, restando-lhe vedada postular objetivo diverso da acendrada identificação da verdade (alcançável, exequível), que no plano jurídico subsume-se matéria prima da justiça.

do processo penal são várias e de similar importância, embora complexas: lograr a condenação do culpado aplicando o chamado Direito penal material, garantir a proteção do inocente evitando sua condenação e assegurando que terá o devido processo, impedir qualquer forma de arbitrariedade na atuação estatal, e chegar a uma sentença justa". Estado de derecho y policía judicial democrática: Notas sobre el alcance e y límites de la investigación policial en el proceso penal, con consideración especial de los actos de mayor relevância, in El proceso penal en el Estado de Derecho (Diez estudios doctrinales), p. 94. 
Nessa conjuntura, releva convir que a pressão pela promoção de segurança pública, notadamente gerada pelos objetivos notoriamente carreiristas ${ }^{49}$ dos governantes (máxime neste país cujos perniciosos vezos e corrompidas práticas políticas ora se encontram desnudados pela "Lava Jato" e demais operações símiles), à sua vez lidimamente cobrados pela massa de eleitores, certamente possui, no mínimo, um enorme potencial de desviar o policial investigador do supra aludido e indeclinável caminho técnico, ético e jurídico de perseguição da verdade, que então poderá se ver substituído, como provavelmente ocorrerá, por uma tão emergencial, quanto obnubilante vereda a ser trilhada segundo a "lógica do culpado" 50 .

\subsection{OS NECESSÁRIOS PRESSUPOSTOS ÉTICOS-POLÍTICOS DA DE- VIDA INVESTIGAÇÃO CRIMINAL.}

Convém, portanto, neste ponto, perquirir como é possível prometer segurança pública num plano onde a impunidade é garantida pelo tão caprichoso, quanto estranho manietamento e/ou bastardeamento precisamente da atividade estatal que, antes de qualquer outra, existe para evitá-la?

49 O carreirismo, segundo Meyrelles, identifica a "política partidária que lastimavelmente se pratica entre nós como meio de galgar e permanecer no poder, através de prestígio eleitoral." (MEIRELLES, Hely Lopes. Direito administrativo brasileiro, p. 40).

50 A "lógica do culpado", nas palavras de Antonio Evaristo Moraes Filho, resta assim elucidada: "Este fenômeno foi muito bem estuda $\neg$ do por Altavilla, em sua famosa "Psico-logia Judiciária" (Porto, 1960, v. 5, p, 36-39), onde dedicou dois verbetes aos perigos das hipóteses provisórias, que podem "seduzir o investigador, de ma $\neg$ neira a torná-lo daltônico na apreciação das conclusões de indagações ulteriores". Adverte o mestre italiano que, una vez internalizada na mente do policial, do promotor ou do juiz, a procedência da hipótese provisória, cria-se em seu espírito a necessidade de demonstrar o quanto considera verdade, 'à qual ele liga uma especial razão de orgulho', como se a eventual demonstração da improcedência de sua hipótese 'constituísse em razão de demérito'. E assim, intoxicado por sua verdade, sobrevaloriza todos os elementos probatórios que lhe forem favoráveis e diminui o 'valor dos contrários, até o ponto de não serem tomados em consideração num auto."' (O Ministério Público e o inquérito policial, p. 106). Noutras palavras, trata-se de uma espécie de armadilha psicológica, que, uma vez ativada, subverte a verdade material, criando um atalho até um "culpado" qualquer, assim denotando uma suposta eficiência repressiva estatal. 
A resposta exigida pelo encimando questionamento, que indiscutivelmente aduz-se de facilitado alcance, remete-nos, contudo, a uma segunda e crucial perquirição, desta vez bem mais complexa, atinente aos efetivos e últimos motivos que invariavelmente levam aqueles que governam ao escancarado desprezo pela função policial judiciária, não apenas flagrantemente preterindo-a em favor da polícia de manutenção da ordem, como privando-a dos meios indispensáveis a garantir o seu proficiente desempenho investigativo.

Tomando por base a atual realidade pátria, desnudada pelos "mensalões", aclarada pela operação "Lava Jato" e suas congêneres, adornada por escândalos de todas as espécies e tamanhos, torna-se imperioso indagar: governantes irresponsáveis e corruptos, quais aqueles que pululam em todos os níveis da nossa federação, irão trabalhar em prol de uma polícia que - porque comprometida com a probidade e a dignidade humana, e além disso eficiente e bem aparelhada - certamente haverá de se voltar contra e coibir as aldabrices do poder político, perpetradas quer por aqueles que ocupam cargos, quer por seus sequazes e aqueloutros favorecidos? ${ }^{51}$ Maria Victória Benevides, tangenciando o tema, identifica como "um dos principais vícios da polícia brasileira (...) a privatização da política, a privatização do poder, em todos os níveis". E explica:

É no nível federal que os governadores se apropriam privadamente do poder e que o fazem em detrimento da sua responsabilidade em relação ao programa de governo, ao atendimento de prioridades públicas; é o representante do Legislativo que usa o seu mandato face aos interesses privados; e pode ser também a privatização dos órgãos policiais, em relação a

51 Embora trazendo em seu corpo uma indefectível refutação, a seguinte notícia, publicada pela Folha de São Paulo, em 04 de novembro de 2011, bem revela as reais possibilidades de manipulação e manietamento da polícia judiciária pelo Poder Executivo estadual. “Investigado, Agnelo troca cúpula da Polícia Civil. Governador do Distrito Federal demitiu 43 delegados e sete diretores do órgão. Áudios da corporação ligam governador a escândalos no Esporte, mas ele nega relação com as demissões." (http://www1.folha.uol.com.br/fsp/poder/po0411201107.htm) 
um determinado governador, em relação a uma determinada corrente política, em relação a determinadas autoridades ou a determinados grupos nos órgãos estatais, em detrimento do interesse público do povo. ${ }^{52}$

Qual o governante, se não verdadeiramente honesto, competente e ainda realizador, que concordará, pois, em conferir alguma autonomia - de direito e não apenas momentânea e faticamente por casuísmo, fraqueza, esperteza ou inaptidão - aos órgãos policiais judiciários, dotando-lhes, ademais, com as condições de investigar não apenas a criminalidade rasteira, mas, também, aquela cometida em detrimento da própria moralidade pública? Qual governante, senão desse jaez, tolerará ser - ele próprio ou seus parceiros e eventuais financiadores eleitorais - eficientemente investigado por profissionais de alto gabarito técnico e ético, sem enxergá-los como estorvos e/ou meros subordinados?

Como, então, com a polícia manietada, poderá a população estar segura em relação àqueles que realmente destroem o Estado Democrático? O que uma polícia inerme poderá contra aqueles que fazem perenes os muitos fatores que conduzem a todas as espécies de criminalidade, quer institucionalizando-os, para proveito próprio e de seus parceiros, quer simplesmente omitindo-se diante dos obstáculos que persistentemente se antepõe à conquista da dignidade humana, como a fome, a ignorância, a corrupção e a injustiça? Contra aqueles que não se acanham em utilizar exatamente essas e outras cadeias para manter as forças policiais incapazes de discernir quem são os verdadeiros e grandes criminosos, empurrando-as cada vez mais para o front nos morros ou periferias, para matar ou morrer, a bem das estatísticas?

Nessa esteira, impõe-se recordar, à guisa de exemplo prático, que em conformidade aos Princípios Orientadores para a Apli-

52 BENEVIDES, Maria Victoria de Mesquita. A polícia sob controle da sociedade a que serve. In : MORAES, Bismael B (Coord.). O papel da polícia no regime democrático, p. $81-82$. 
cação Efetiva do Código de Conduta para os Funcionários Responsáveis pela Aplicação da Lei - uma espécie de Código de Ética Policial da ONU, "todos os funcionários responsáveis pela aplicação da Lei devem ser satisfatoriamente remunerados e beneficiar de condições de trabalho adequadas". Porém, ao fazer ouvidos moucos às constantes reivindicações remuneratórias e por condições de trabalho que, absolutamente afinadas com o espírito constitucional, animam a justa expectativa de uma existência digna dos responsáveis pelo exercício policial judiciário, nossos governantes, em sentido diametralmente oposto, acabam, na prática, por oficializar os mecanismos que irrefragavelmente impõem o desalento e até mesmo estimulam a corrupção. Ademais, tal proceder - talvez simples fruto de negligência ou preconceito, talvez mais do que isso -, lastimavelmente se apresente recorrente entre nós, qual afiança Guaracy Mingardi:

A corrupção é um fenômeno que atinge praticamente todas as polícias do mundo. No Brasil, a situação se agrava porque os governantes fazem vista grossa para algumas irregularidades, pois assim podem manter baixo os salários dos policiais. Houve um governador paulista que, quando os policiais ameaçaram greve, disse que eles tinham arma e carteirinha, portanto poderiam se virar, não precisavam de aumento. ${ }^{53}$

53 MINGARDI, Guaracy. Como enfrentar o aumento da criminalidade, p. C3. Nesse mesmo diapasão, a Convenção Interamericana Contra a Corrupção insistiu para que todas as medidas preventivas voltadas a esse combate sempre "levem em conta a relação entre uma remuneração eqüitativa e a probidade no serviço público" (art. III, 12). E longe de se constituir num testemunho isolado, o referido pronunciamento se vê plenamente corroborado pelo irretorquível escólio de Nilo Batista: "Entre as instituições da área de justiça e segurança pública, a polícia é uma espécie de "gata borralheira", jamais convidada para o baile dos teóricos, mas sempre muito comentada neles. Sobre ela incide uma empobrecedora redução dual: violência e corrupção. Não se trata, por certo, de negar o binômio violência e corrupção (episódicas ou sistemáticas, conforme a partitura e o maestro). Porém, se estamos interessados em conceber uma polícia para o estado de direito democrático, convém superar esse reducionismo cego. Convém, por exemplo, perguntar se uma sociedade que não exerce, a partir de sua própria forma de organização, a solidariedade e a fraternidade, ou cujas práticas políticas não conheçam a experiência da tolerância e da participação - em suma, uma sociedade organicamente violenta e produtora da violência - pode ter uma polícia em que o respeito ao outro prevaleça sobre a truculência. Convém 
Não há, ademais, como não atentar para o alerta de Hassemer, feito no sentido de que a estabilização da criminalidade organizada passa necessariamente pela "corrupção da persecução penal", como meio de "influenciar criminosamente a definição, a elucidação ou o julgamento das violações penais" ${ }^{54}$. Dessa forma, e diversamente do que ocorre na realidade cotidianamente constatada, a otimização da função investigatória avulta absolutamente indispensável, se não imediatamente como garantia de justiça, sua natural finalidade, ao menos, e reflexamente, para evitar o degringolamento da ordem pública democrática.

Importa registrar que, nos Estados Unidos, credita-se ao afastamento da influência política das atividades policiais o grande trunfo de J. Edgar Hoover na transformação do FBI no mais famoso e festejado órgão policial investigativo do mundo, indiscutível referência em termos de sucesso, eficiência e seriedade para toda e qualquer polícia do gênero. Conta Ralph De Toledano que, convidado, aos 29 anos, para assumir a direção do Birô - que àquela altura, maio de 1924, encontrava-se envolvido em toda sorte de escândalos e denúncias de corrupção -, Hoover condicionou sua aceitação à garantia de que não mais seriam toleradas intromissões políticas no órgão, de modo que as indicações e promoções futuras passariam a depender exclusivamente de mérito pessoal e de habilidade comprovada ${ }^{55}$. Atendido em sua exigência, manteve-se à sua testa por 48 anos, sendo considerado o principal responsável pelo conceito, respeitabilidade e perícia que a agência hoje ostenta.

igualmente perguntar se num país cuja administração pública tem uma história que é um hino à esperteza, uma sucessão de negociatas, "comissões", ganhos ilícitos, tudo tradicionalmente impune, poderíamos encontrar na administração policial um oásis de austeridade e zelo. Como comparar os mais escabrosos casos de corrupção policial aos mais episódios de corrupção na área monetária e financeira, senão como um modestíssimo varejo diante de um jamais punido atacado." (BATISTA, Nilo. Punidos e mal pagos: violência, justiça, segurança pública e direitos humanos no Brasil de hoje, p. 170..)

54 HASSEMER, Wifried. Op. cit., p. 59.

55 DE TOLEDANO, Ralf. Edgar Hoover: the man in his time, p. 71. No mesmo sentido: FLOHERTY, John J., Our FBI: an inside story, p. 17. 


\section{EM CONCLUSÃo: DA IMPRESCINDÍVEL AUTONOMIA DA POLÍCIA JUDICIÁRIA BRASILEIRA.}

Vê-se, pois, que obrigatoriamente há de se dar uma vez mais merecida razão a Ferrajoli quando exige que a polícia judiciária - identifica como aquela destinada à "investigação dos crimes e a execução dos provimentos jurisdicionais" - deva "ser separada rigidamente dos outros corpos de polícia e dotada, em relação ao Executivo, das mesmas garantias de independência que são asseguradas ao Poder Judiciário do qual deveria, exclusivamente, depender." 56

Mediante esse proposto distanciamento, ver-se-ia a polícia judiciária da protegida da conhecida politicagem governamental, em conjuntura que não apenas libertará a atividade investigativa inerente à essa função da ruinosa influência política partidária que tão bem vinca a gestão executiva neste nosso país de tradições autoritárias, ímprobas e excludentes, como também liberará seus responsáveis e executores para ocupar-se exclusivamente das tarefas e dos objetivos inerentes à justiça criminal, a óbvia razão de sua existência.

Mister recordar, entretanto, que o $\S 60$ do art. 144 da vigente Constituição da República ora explicitamente subordina as policiais civis dos Estados, órgãos competentes para o exercício da polícia judiciária, aos respectivos Governadores. Destarte, parece providencial indagar: como seria possível proceder a essa necessária cisão? Decerto que a correspondente resposta deve tocar na reforma da Constituição, inicialmente retirando a polícia judiciária do capítulo da segurança pública, para situá-la, pelos motivos acima plasmados, com vinculação técnica com o Poder Judiciário, em seção específica do capítulo constitucional devotado às funções essenciais à justiça (capítulo IV do título III).

56 FERRAJOLI, Luigi. Op. cit., p. 617. Grifo não original. 
Em favor dessa mudança recordamos Frederico Marques, que acerca de sua imperiosidade já aduzia há muitas décadas:

De tudo se conclui que a polícia judiciária precisa ser aparelhada para tão alta missão, tanto mais que o Código de Processo Penal a prezê expressamente no art. $6^{\circ}$, item IX. Para tanto seria necessário uma reforma de base, tal como preconizaram Sebastián Soler e Velez Mariconde na Exposição de Motivos do Código de Processo Penal de Córdoba, em que se estruturasse a polícia judiciária em quadros próprios, separando-a da polícia de segurança e da polícia política. Reorganizada em bases científicas, e cercada de garantias que a afastem das influências e injunções de ordem partidária, a polícia judiciária, que é das peças mais importantes e fundamentais da justiça penal, estará apta para tão alta e difícil tarefa. ${ }^{57}$

Seguindo os passos desse eminente processualista, cremos que o grande e efetivo calcanhar de Aquiles que pode ser inapelavelmente diagnosticado na organização das polícias, e especialmente daquelas de vocação investigativas, atine à imbricação com as instâncias materiais do poder, como acima demonstrado.

É certo, pois, que a manutenção da polícia judiciária no âmbito de influência do Poder Executivo nenhum benefício pode trazer aos objetivos democráticos e democratizantes ínsitos na vigente Constituição da República, donde, em defesa dos valores positivados em nosso ordenamento jurídico-político, ora se impõe, à adequada correção de rumo, acatar a diretriz garantista de Ferrajoli, deslocando a cuidada função investigativa, no bojo do órgão apropriado, para a órbita judiciária.

Essa proposta recebe a veemente adesão de Juan-Luis Gomes Colomer, que alerta para a impossibilidade de se garantir uma investigação eficaz, realizada dentro dos parâmetros garan-

57 MARQUES, Frederico. Op. cit., p. 176. 
tistas, à míngua de uma polícia judiciária organizada e autenticamente profissional, "desvinculada do Poder executivo" ${ }^{58}$.

A autonomia da Polícia Judiciária deve, portanto, ser alavanca em favor da renovação desse discorrido cenário, e, pois, como inelutável prioridade, mormente em face dos acontecimentos que recentemente pontuaram a vida política brasileira, vinculados à supostas tentativas e ameaças de coação das atividades investigativas levadas a efeito na "Operação Lava Jato", pela Polícia Federal, perpetradas em desfavor da corrupção e da ditadura do poder econômico.

Outrossim, e numa segunda e também importante direção, presta-se a telada medida a realizar, nos termos preludialmente proclamados por Ferrajoli, a definitiva cisão das atividades policiais preventivas e investigativas, cuja mescla mereceu de Rusconi, não a toa, o rótulo de "promiscuidade funcional", porquanto, como fruto dessa perniciosa amálgama, é de se reconhecer que a "tendência autoritária proveniente da atividade preventiva invade aos poucos as tarefas de investigação processual" ${ }^{59}$.

Importa registrar, nessa direção, que um passo importante já foi dado colimando a discorrida inovação, tendo, em 10 de março de 2008, o Egrégio Conselho Federal da Ordem dos Advogados do Brasil (Pleno) aprovado - com o voto favorável e decisivo do Conselheiro Relator, o insigne processualista e professor Jacinto Nelson de Miranda Coutinho ${ }^{60}$ - proposta de Emenda Constitucional, da la-

58 COLOMER, Juan-Luis Gómez. A investigação criminal: problemas atuais e perspectivas de unificação internacional, p. 219-220. Mesmo não se esquecendo que a questão enfrentará "tremenda oposição" da parte do Poder político, insiste o autor nesse caminho que considera o único que poderá conduzir à edificação de "uma verdadeira Justiça Penal".

59 RUSCONI, Maximiliano A. Reformulación de los sistemas de justicia penal em América Latina y policía : algunas reflexiones. Pena y Estado : policía e sociedad democrática, p. 194.

60 Publicado na edição inaugural desta Revista, às páginas 13/23. 
vra do ilustre Professor Doutor Fábio Konder Comparato, tendente a conferir autonomia funcional e institucional à polícia judiciária. :

Convém destacar que a mencionada proposta não copia nenhum sistema alienígena ${ }^{61}$. Ao contrário, funda-se nas melhores experiências pátrias, que serviram de molde não apenas para a institucionalização da autonomia policial judiciária, como também para o incremento e a otimização dos correspondentes mecanismos de controle dessa atividade.

É de se ponderar que a diversidade de sistemas policiais estrangeiros - cada qual afeto unicamente às peculiaridades da história, das tradições e da cultura dos povos a que servem - bem denota a inviabilidade dos projetos calcados em modelos afins, assim na exata medida em que sempre se aduzem alicerçados sobre premissas e pressupostos que não se repetem neste nosso único e, por vezes, até excêntrico Brasil.

Por derradeiro, e com o objetivo explícito de não se fechar questão, mas por desejar, absolutamente em mão diversa, fomentar tal debate, consigna-se que a materialização da telada autonomia, certamente poderia vir a se concretizar por meio de específica formatação autárquica, sob as bênçãos e a inspiração do princípio administrativo da especialidade.

Impõe-se neste ponto esclarecer que autonomia não pode ser confundida com independência, seguindo, pois, a polícia judiciária, enquanto o seu exercício estiver confiado à entidade au-

61 Atitude louvada por Geraldo Ataliba: “Também tem influenciado negativamente o conhecimento e a aplicação do nosso direito constitucional uma falsa valorização do direito comparado. Ao contrário de se meditar sobre direito estrangeiro, para fecundar um estudo crítico de nossas instituições, 'escritores' apressados transplantam sem critérios institutos, problemas e 'soluções' que nada tem a ver com nosso Texto, ou com nossas peculiaridades". E mais, assim com vistas ao tanto já apresentado: “Nessa ordem de idéias surgiu a teoria, amparada pelo direito positivo de outros países, de 'Executivo forte', de tão desastrosos e deletérios efeitos na nossa prática constitucional e na nossa jurisprudência" (República e Constituição, p. 20). 
tárquica, obviamente sujeita à lei e a todos os demais princípios que vincam as atividades públicas (moralidade, impessoalidade, publicidade, eficiência, interesse público, devido processo legal, razoabilidade, proporcionalidade, tutela e autotutela etc.), bem assim aos controles externos e internos que se lhe afigurarem constitucional e legalmente impositivos.

Por derradeiro, há de se consignar que, embora não precisamente nos precedentes moldes, que se parecem próprios ao figurino que veste sob medida as vicissitudes especificamente brasileiras, a almejada disjunção em foco já foi realizada alhures, e com bastanteo êxito, como informa Bailey:

Santa Ana é uma cidade charter, o que significa que é dirigida por um Administrador Municipal profissional. Esse sistema foi idealizado para manter os órgãos do governo afastados do envolvimento direto em política eleitoral, e sua aplicação teve amplo sucesso. O sistema, muito empregado na Costa Oeste, é responsável, talvez mais do que qualquer outro fator isolado, pela ausência geral de corrupção nos departamentos de polícia do Oeste. Mas essa talvez não seja a maneira correta de formular a relação entre a organização de governo municipal e a corrupção da policia. Pode ser que o sistema de administrador contratado não seja tão bom, mas sua alternativa clássica do Leste, o sistema dirigido por um prefeito eleito, seja fundamentalmente ruim.

Nos lugares onde predominava o sistema de prefeito eleito, a máquina política influenciava de modo errado a escolha do chefe de polícia, a promoção e a escala de serviço e até mesmo o ingresso no departamento. A máquina política precisava de fundos para reeleger seus candidatos e uma grande porção desses fundos era obtida em atividades ilegais, classicamente jogo e prostituição. Os negociantes do vício devolviam parte dos lucros aos políticos da máquina e aos policiais. Os salários da polícia podiam continuar relativamente baixos, porque seriam aumentados rotineiramente por envelopes de pagamento semanais que os próprios policiais dividiam entre si." 62

62 BAYLEY, David H., SKOLNICK, Jerome H. Nova polícia: inovações na polícia de seis 
Embora tal fórmula não tenha aplicabilidade por estas plagas, presta-se a encimada experiência a afiançar a correção da pretensão de ver a polícia judiciária blindada em face dos comezinhos desvios do poder político, a fim de que as investigações que se lhe afiguram inerentes e obrigatórias sirvam não à repressão, mas sim que tenham a valia de instrumentos da justiça, a qual que haverão então de auspiciar mediante o farto oferecimento, ao Poder que diz o direito, das provas hábeis, coligidas com isenção e eficiência, à restauração da verdade sobre um fato tido como criminoso, e assim aptas a desvelar a culpa ou a inocência de seu efetivo autor. No primeiro caso, viabilizará a justa condenação de um delinquente, não se lhe permitindo que escape das consequências de sua ação vil; já no segundo, ensejará àquele que nada deve, em contexto de idêntica magnitude, livrar-se dos tormentos de um injusto processo (promovendo o "filtro processual" a que alude Aury Lopes Filho, dito fundamental a elidir os terríveis malefícios das denominadas "sanções ante, extra ou ultra delictum, às quais, com base no magistério de Ferrajoli, reporta-se o mesmo autor ${ }^{63}$ ).

Em ambos os casos, ganham o indivíduo e a sociedade, pois como advertia Karl Popper,"devemos fazer planos para a liberdade, e não só para a segurança, ainda que pela única razão de só a liberdade poder tornar a segurança segura."

cidades norte-americanas, p. 32-33. Mister alertar que tal medida não é solução para todos os males, servindo, como se viu, a resolver a contento o problema endêmico da corrupção. Todavia, acrescenta o autor, restou uma residual deficiência a ser sanada: “No conjunto, os departamentos de polícia da Costa Oeste não têm tido problemas de corrupção, mas têm sido acusados de manter-se distantes e isolados das comunidades a que servem. Como a polícia está isolada da política, seu 'profissionalismo' podem assumir um estilo arrogante, particularmente quando lidam com minorias que têm pouca influência junto a um administrador municipal ou a um chefe de polícias. Além disso, as minorias - sobretudo negros e hispânicos - não incorporam a idéia que um policial médio tem do cidadão honrado cujos direitos e bens devem ser respeitados" (p. 33).

63 LOPES JR. Aury. Op. cit., p. 223-228. 


\section{REFERÊNCIAS BibLIOGRÁFICAS}

ALMEIDA, J. Canuto Mendes de. Princípios fundamentais do processo penal. São Paulo: RT, 1973.

ATALIBA, Geraldo. República e Constituição. 2 ed. atual. por Rosolea Miranda Folgosi. São Paulo: Malheiros, 2001.

BANDEIRA DE MELLO, Celso Antonio. Curso de direito administrativo. 14. ed. refundida, ampl. e atual. até a EC no 35, de 20.12.2001. São Paulo: Malheiros, 2002.

BATISTA, Nilo. Punidos e mal pagos: violência, justiça, segurança pública e direitos humanos no Brasil de hoje. Rio de Janeiro: Revan, 1990.

BAYLEY, David H. SKOLNICK, Jerome H. Nova polícia: inovações na polícia de seis cidades norte-americanas. Trad. Geraldo Gerson de Souza. São Paulo: EDUSP, 2001 (Série Polícia e Sociedade, n. 2).

BENEVIDES, Maria Victoria de Mesquita. A polícia sob controle da sociedade a que serve. In : MORAES, Bismael B (Coord.). O papel da polícia no regime democrático. São Paulo: Mageart, 1996, p. 71-87

BERISTAIN, Antonio. Ética Policial Segun Las Naciones Unidas. Justitia. Tradução livre do autor. São Paulo: Ministério Público de São Paulo, v. 125, p. 21-46, abr.-jun. 1984

CANOTILHO, J. J. Gomes. Direito constitucional e teoria da Constituição. 3. ed. Coimbra: Almedina, 1999.

COLOMER, Juan-Luis Gómez. A Investigação Criminal Problemas Atuais e Perspectivas de Unificação Internacional. In: CHOKR, Fauzi Hassan; AMBOS, Kai (Coords). Processo Penal e Estado de Direito. Campinas : Edicamp, p. 199-244, 2000. 
. Estado de Derecho y Policía Judicial Democrática : Nota sobre el alcance y límites de la investigación policial en el proceso penal, com consideración especial de los actos de mayor relevancia. El proceso penal en el Estado de Derecho (Diez estudios doctrinales). Trad. livre do autor. Castellón (Espanha): Palestra Editores, 1999, 93-123.

CRETELLA JÚNIOR, José. Do poder de polícia. Rio de Janeiro. Forense, 1999.

CUNHA RODRIGUES, José Narciso. Para um novo conceito de polícia. Revista Portuguesa de Ciência Criminal. Coimbra: Coimbra Editora, fasc. 3o, p. 389-408, jul.-set. 1998.

DE PLÁCIDO E SILVA. Vocabulário jurídico. 1. ed. eletrônica. Rio de Janeiro: Forense, 1999. CD-ROM.

DE TOLEDANO, Ralf. J. Edgar Hoover: the man in his time. New Rochele: Arlington House, 1973.

DIAS NETO, Theodomiro. Segurança Pública: Um conceito a ser Repensado. Boletim IBCCrim. São Paulo: Instituto Brasileiro de Ciências Criminais, n. 58, Ed. Especial, p. 12, set. 1997.

DINIZ, Maria Helena. Dicionário Jurídico. São Paulo: Saraiva, 1988, vol. 3 (J-P).

DI PIETRO, Maria Sylvia Zanella. Direito Administrativo. 15a ed. São Paulo: Atlas, 2003.

DOTTI, René Ariel. Reforma penal brasileira. Rio de Janeiro: Forense, 1988.

FERRAJOLI, Luigi. Direito e razão: teoria do garantismo penal. Tradução de Ana Paula Zomer et al. São Paulo: RT, 2002.

FLOHERTY, John J.. Our FBI: an inside story. 6. ed. Philadelphia \& New York: J. B. Lippincott Company, 1951. 
FREDERICO MARQUES, José. Elementos de direito processual penal - Vol. I. Campinas: Bookseller, 1997.

HASSEMER, Winfried. Segurança pública no estado de direito. Tradução de Carlos Eduardo Vasconcelos. Revista Brasileira de Ciências Criminais. São Paulo: RT: Instituto Brasileiro de Ciências Criminais, n. 5. p. 55-69, jan.-mar. 1994.

LOPES JR. Aury. Direito Processual Penal e sua conformidade constitucional. $7^{\mathrm{a}}$ ed. Rio de Janeiro: Lumen Juris Editora, 2011. vol. I, p. 223-228.

MALCHER, José Lisboa Gama. Manual de direito penal brasileiro. Rio de Janeiro: Freitas Bastos, 1980.

MARTINEZ, Roberto Perez. La policía judicial en el Estado democrático de derecho. Pena y estado : policía e sociedad democrática.. Trad. livre do autor. Buenos Aires: Editores del Puerto s.r.l., n. 3, jul. 1998.

MASAGÃO, Mario. Curso de Direito Administrativo. São Paulo : Max Limonad, 1960.

MEIRELLES, Hely Lopes. Direito administrativo brasileiro. 24. ed. atual. por Eurico de Andrade Azevedo, Délcio Balestero Aleixo e José Emmanuel Burle Filho. São Paulo: Malheiros, 1999. . Polícia de Manutenção da Ordem Pública e suas Atribuições. In: CRETELLA JÚNIOR, José (Coord.). Direito Administrativo da Ordem Pública. 3a ed. Rio de Janeiro: Forense, 1998, p. 87-93.

MENDES JÚNIOR, João. O processo criminal brasileiro. Rio de Janeiro: Laemmert \& C., 1901.

MESQUITA, Paulo Dá. Notas sobre inquérito penal, polícias e Estado de direito democrático (suscitadas por uma proposta de lei dita de organização da investigação 
criminal). Revista do Ministério Público. Lisboa :

Procuradoria Geral da República, n. 82, p. 137-149, abr./ jun. 2000.

MINGARDI, Guaracy. Como enfrentar o aumento da criminalidade. Jornal O Estado de São Paulo. São Paulo, 27 jan. 2002, Cidades, p. C3.

MORAES FILHO, Antonio Evaristo. O Ministério Público e o inquérito policial. RBCCrim. São Paulo: Editora Revista dos Tribunais, n 19, jul-set, 1997, p. 106.

MOREIRA NETO, Diogo de Figueiredo. Direito Administrativo da Segurança Pública. In : CRETELLA JÚNIOR, José (Coord.). Direito Administrativo da Ordem Pública. 3 ed. Rio de Janeiro : Forense, 1998, p. 65-86.

NUCCI, Guilherme de Souza. Código de Processo Penal Comentado. 15 ed. Rio de Janeiro: Forense, 2016.

PEREIRA, Eliomar da Silva. Convencionalismo e dogmatismo no conceito de crime como objeto de investigação criminal. Doutrinas essenciais: Direito Penal e Processo Penal. BADARÓ, Gustavo Henrique (Org.). São Paulo: Editora Revista dos Tribunais, vol. VI, 2015.

PIMENTA BUENO, José Antonio. Apontamentos sobre o processo criminal brasileiro. 5. ed. Rio de Janeiro: Jacintho Ribeiro dos Santos Editor, 1922.

PITOMBO, Inquérito Policial : novas tendências. Belém: CEJUP, 1986.

RUSCONI, Maximiliano A. Reformulación de los sistemas de justicia penal em América Latina y policía : algunas reflexiones. Pena y Estado: policía e sociedad democrática. Buenos Aires : Editores del Puerto s.r.l., n. 3, p. 189-198, jul. 1998.

SILVA, José Afonso da. Curso de direito constitucional positivo. 20. ed. rev. e atual. São Paulo: Malheiros, 2002. 
SUNDFELD, Carlos Ari. Direito Administrativo Ordenador. São Paulo: Malheiros, 1997.

TORNAGUI, Hélio. Instituições de processo penal. Rio de Janeiro: Forense, 1959.

TOURINHO FILHO, Fernando da Costa. Processo Penal. 6. ed. São Paulo, Saraiva, vol 1, 1982.

ZACCARIOTTO, José Pedro. Portaria DGP 18/98 e polícia judiciária democrática. Revista dos Tribunais. São Paulo: Editora Revista dos Tribunais, v. 769, nov. 1999, p. 459479 . 